\title{
Policy Watch: Government Analysis of the Benefits and Costs of Regulation
}

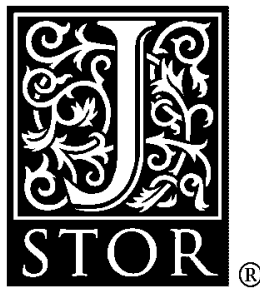

\author{
Robert W. Hahn
}

The Journal of Economic Perspectives, Vol. 12, No. 4. (Autumn, 1998), pp. 201-210.

Stable URL:

http://links.jstor.org/sici?sici=0895-3309\%28199823\%2912\%3A4\%3C201\%3APWGAOT\%3E2.0.CO\%3B2-5

The Journal of Economic Perspectives is currently published by American Economic Association.

Your use of the JSTOR archive indicates your acceptance of JSTOR's Terms and Conditions of Use, available at

http://www.jstor.org/about/terms.html. JSTOR's Terms and Conditions of Use provides, in part, that unless you have obtained prior permission, you may not download an entire issue of a journal or multiple copies of articles, and you may use content in the JSTOR archive only for your personal, non-commercial use.

Please contact the publisher regarding any further use of this work. Publisher contact information may be obtained at http://www.jstor.org/journals/aea.html.

Each copy of any part of a JSTOR transmission must contain the same copyright notice that appears on the screen or printed page of such transmission.

The JSTOR Archive is a trusted digital repository providing for long-term preservation and access to leading academic journals and scholarly literature from around the world. The Archive is supported by libraries, scholarly societies, publishers, and foundations. It is an initiative of JSTOR, a not-for-profit organization with a mission to help the scholarly community take advantage of advances in technology. For more information regarding JSTOR, please contact support@ jstor.org. 


\title{
Policy Watch
}

\section{Government Analysis of the Benefits and Costs of Regulation}

\author{
Robert W. Hahn
}

This feature contains short articles on topics that are currently on the agendas of policymakers, thus illustrating the role of economic analysis in illuminating current debates. Suggestions for future columns and comments on past ones should be sent to C. Eugene Steuerle, c/o Journal of Economic Perspectives, The Urban Institute, 2100 M Street NW, Washington, D.C. 20037.

\section{Introduction}

Expenditures incurred because of federal environmental, health, and safety regulation have grown dramatically in recent decades, and now total several hundred billion dollars annually. These costs appear likely to increase significantly in the next decade, as well. Yet the economic impacts of regulation receive much less scrutiny than direct, budgeted government spending. The potential gains of regulatory reform are substantial. Research suggests that more than half of the federal government's regulations would fail a strict benefit-cost test using the government's own numbers (Hahn, 1998). There is ample research suggesting that regulation could be significantly improved, so that we could save more lives with fewer resources (Morrall, 1986; Viscusi, 1996). One study found that a reallocation of mandated expenditures toward those regulations with the highest payoff to society could save as many as 60,000 more lives a year at no additional cost (Tengs and Graham, 1996).

Recently, Congress has begun to show a greater interest in assessing the economic impact of regulation. In 1996, Senator Ted Stevens of Alaska added an

Robert W. Hahn is Director of the AEI-Brookings Joint Center for Regulatory Studies, Washington, D.C., and Research Associate, Kennedy School of Government, Harvard University, Cambridge, Massachusetts. 
amendment to the Omnibus Consolidated Appropriations Act of 1997 that required the director of the Office of Management and Budget (OMB) to provide Congress with estimates of the total annual benefits and costs of all federal regulatory programs and estimates of the benefits and costs of individual regulations. This statute was the first to mandate such an accounting. In September 1997, the OMB produced its first report on the benefits and costs of regulation in response to the Stevens amendment, available on the web at /http://www.whitehouse.gov/WH/ $\mathrm{EOP} / \mathrm{OMB} / \mathrm{html} / \mathrm{rcongress} . \mathrm{htm}\rangle$, and it recently completed a second report in the fall of 1998. At this point it is not clear whether Congress will require additional reports. This essay reviews the increasing use of economic analysis in regulatory decision-making, assesses the first OMB report, and considers how the use of economic analysis can help to inform regulatory decision-making.

\section{Economic Analysis and Regulatory Reform: An Overview}

The last six presidents have introduced different regulatory oversight mechanisms, with varying degrees of success. In 1971, President Nixon established a "Quality of Life Review" of selected regulations, under which the OMB required agencies issuing regulations affecting health, safety, and the environment to coordinate their activities. President Ford formalized and broadened the review process in Executive Order 11821, which required that agencies prepare economic impact analyses for $\mathrm{OMB}$ review for rules whose annual impact typically exceeded $\$ 100$ million. In 1978 President Carter issued Executive Order 12044, which required detailed regulatory analyses of proposed rule-makings and review by the Executive Office of the President. In addition, he established two interagency groups. The Regulatory Analysis Review Group, comprised of representatives from the Executive Office of the President and regulatory agencies, examined a limited number of proposed regulations expected to have substantial regulatory impact. The Regulatory Council, consisting of the heads of federal regulatory agencies, was asked to publish a Calendar of Federal Regulations, which summarized major regulations under development and was designed to point out regulatory overlap and to describe the benefits and costs of the proposed actions.

The Reagan administration both broadened the scope of the regulatory review and required estimates of costs and benefits for major regulations. Just after entering office, President Reagan announced the formation of his interagency Task Force on Regulatory Relief to be chaired by Vice President Bush, which focused on reviewing existing regulations. Reagan also issued Executive Order 12291, requiring agencies to conduct benefit-cost analyses for all proposed major rules. Although the OMB could not veto agency rules, it did have the power to send the analysis back to the agency for reconsideration. A second executive order by Reagan required annual publication of the Regulatory Program of the United States, which reviewed regulations proposed by agencies for conformance with administration policy and priorities. The Bush administration replaced the Task Force on Regulatory Relief with the Council on Competitiveness, headed by Vice President Quayle. Pres- 
ident Clinton replaced the Reagan Executive Order 12291 with Executive Order 12886, which requires similar regulatory analyses. In addition, Clinton initiated a National Performance Review aimed at helping to "reinvent government."

Following the Clinton initiatives, the 104th Congress made passionate pleas for designing smarter, more efficient regulation, but several comprehensive regulatory reform bills, which called for greater use of benefit-cost analysis and improved risk assessment, failed to pass. However, while far-reaching reforms failed, some legislation was passed that increased congressional oversight of regulation. Examples include the Unfunded Mandates Reform Act of 1995, the Small Business Regulatory Enforcement Fairness Act of 1996, and the Stevens amendment. While the thrusts of each piece of legislation and the Clinton executive order differ, they share a requirement that agencies take further steps to assess the benefits and costs of different kinds of regulations.

Many states are also moving toward a systematic analysis of significant regulatory actions. According to a 1996 survey by the National Association on Administrative Rules Review, administrative law review officials in 27 states noted that their state statutes require economic impact analysis for all proposed rules, and 10 states require benefit-cost analysis for all proposed rules. However, the level of compliance with those requirements, the quality of the analysis conducted, and their influence on decision-making are not clear.

The economic analysis of regulatory decisions is also increasing worldwide (Guasch and Hahn, forthcoming). However, an OECD (1997) study of 18 countries (including the United States) that require some assessment of the impacts of their regulations concluded that at least so far, those analyses generally only have a "marginal influence" on decision-making. Nonetheless, the trend toward formally considering economic benefits and costs in regulatory decision-making at all levels of government is likely to continue.

\section{The First OMB Report on the Benefits and Costs of Regulation}

In its report to Congress on the benefits and costs of regulation, the OMB (1997) defines federal regulation as statements issued by federal regulatory agencies such as the Environmental Protection Agency and the Federal Communications Commission to implement, interpret, or prescribe laws. The report distinguishes between social regulation, such as environmental, health, and safety regulation, and economic regulation, which addresses control of entry and/or prices and some labor market regulation. It also includes a category for process regulation, often referred to as paperwork or disclosure regulation, which includes the administrative burdens of filing forms and reporting information to comply with regulations.

To derive an estimate of the total benefits and costs of regulation, the OMB (1997) report begins with an estimate by Hahn and Hird (1991). That study reviewed and normalized available estimates of the gains from deregulating specific sectors of the economy as well as estimates of the net benefits of federal regulatory programs aimed at protecting health, safety and the environment. The report also 
used an estimate of the cost of environmental regulation (U.S. EPA, 1990). To update those numbers to 1997 , the report considers more recent work that identifies the benefits and costs of individual social regulations between 1990 and 1995 (OMB, 1996b; Hahn, 1996). It updates the estimate of the costs of economic regulation by adding some costs of transportation and banking from Hopkins's (1992) update of Hahn and Hird and then reduces those costs to account for some recent banking and telecommunications deregulation.

For 1997, the OMB estimates that the benefits of environmental regulation were $\$ 162$ billion and the benefits for "other social regulation" were $\$ 136$ billion (in 1996 dollars). The costs for those two categories were $\$ 144$ billion and $\$ 54$ billion, respectively. So for social regulation, the aggregate annual benefits were about $\$ 300$ billion, and the aggregate annual costs were about $\$ 200$ billion-with environmental regulation accounting for a major share of both benefits and costs. The OMB also finds costs of $\$ 71$ billion for economic regulation and $\$ 10$ billion for paperwork. The agency makes no attempt to estimate the benefits of economic regulation or paperwork, although it suggests that those benefits could be significant, and gives examples like information disclosure requirements in the financial sector.

In addition to examining the total benefits and costs of regulations, the report provides some benefit and cost information on 41 regulations with annual gross costs of $\$ 100$ million or more. The OMB focused its discussion on 21 of those regulations that have a direct impact on the private sector; the other 20 of the regulations were rules necessary to implement federal budgetary programs. This section of the report summarizes some information that is not easy to obtain. For example, seven of the 21 rules summarized by the OMB in the report have positive monetized net benefits. In six other cases, regulatory assessments noted benefits that were quantified, but not monetized.

The final section of the main report provides recommendations. It argues that the existing data on benefits and costs of programs would not support a recommendation to eliminate or reform any particular program. It highlights the problems with aggregate estimates and notes the need for more and better analysis of individual regulations. It also notes some problems with the general quality of analysis performed by the regulatory agencies. The report then suggests how the regulatory oversight arm of the OMB can play an important role in improving the quality of analysis and in developing a database on the benefits and costs of major rules. For the most part, those recommendations build on a consensus emerging within the economics community on how to improve the quality of regulatory analysis (Arrow et al., 1996; Crandall et al., 1997). Key recommendations include following "best practice" guidelines, estimating the economic impact of regulations after they are in place, using consistent assumptions to compare the effectiveness of regulations, and developing a better database. These next few sections consider potential improvements in several areas: issues related to the cost and benefit estimates in the report, and some recommendations for improving the quality of economic analysis in the regulatory process. 


\section{Estimating Benefits and Costs}

The OMB (1997) report does recognize many of the methodological issues involved with the aggregate estimates of benefits and costs. As they note, the "substance is in the details, not in the total." However, future reports could be significantly improved by more carefully evaluating the methodology for estimating total benefits and costs.

One potentially serious problem with the report's aggregate estimates is that they combine a baseline estimate of actual compliance costs of regulation with estimates of the expected costs of future regulations, with an assumption of full implementation and compliance. For example, the baseline for environmental costs is an EPA (1990) estimate for 1988 that relies primarily on historical survey information on government and private expenditures. The OMB then adds assessments of potential costs from government regulatory analyses of major regulation between 1987 to 1996 . For other costs of social regulation, the baseline estimate is a Hahn and Hird (1991) estimate for 1988 that relies on retrospective studies on the economic impact of regulations in general areas such as highway safety and drug approval. However, the baseline cost estimates are not directly comparable with the estimated incremental costs in the government regulatory analyses, and it is not clear how best to combine them. The OMB report did not address that issue.

The estimate of the cost of economic regulation also has some problems. For example, the OMB calculates the additional costs from banking regulations in the early 1990s based on a study that the General Accounting Office (1993) criticizes for having a poor survey design and low response rates. Moreover, it is focused more on paperwork compliance costs than on efficiency costs. Then, the OMB's downward adjustment for recent deregulation of banking seems to be a back-ofthe-envelope calculation with little empirical support.

A second broad problem area is that the report fails to assess how critical assumptions affect the net benefit estimates. For example, the OMB did not include a rule related to stratospheric ozone (apparently because it was not in the Hahn [1996] database); if it had, the benefit-cost ratio would have been orders of magnitude higher. As another example, the OMB relied on a measure that included a number of questionable cost savings, such as savings from productivity gains and the avoided costs of cleanup. Excluding those savings would mean that total costs just exceed total benefits. Without quarreling about the validity of such estimates, future OMB reports should certainly highlight such key sensitivities. They should also examine how key economic parameters affect results, such as the value of life, the discount rate and the level of compliance with the rule.

A third problem is that the $\mathrm{OMB}$ does not provide a quantitative assessment of the uncertainties in its estimates, though it notes they could be substantial. How much confidence should be placed in the OMB's estimates that the annual benefits of social regulation exceed annual costs by about $\$ 100$ billion? On the benefit side, not all the benefits of regulation can be quantified or monetized. On the cost side, regulation may have potentially adverse impacts on investment, productivity and market structure, which are not captured in the estimates (Hazilla and Kopp, 1990; Jaffe et 
al., 1995). For example, firms frequently make strategic use of the regulatory process to increase barriers to entry in an industry, which can reduce competition and consumer welfare. Regulators can affect a firm's behavior in subtle ways simply by having the ability to pass regulations and enforce laws selectively in ways that could hurt the firm. There is growing evidence that economic deregulation has had substantial positive impact on productivity over time (Winston, 1998), which implies that the lack of such productivity growth should be counted as a cost of economic regulation. These questions are very difficult and few systematic studies have attempted to answer them. It is probably wise that the OMB chose not to explore those issues in detail in its first report. Nonetheless, such issues deserve to be acknowledged.

\section{Recommendations for Improving the Quality of Analysis}

The OMB can do a number of things to help improve our understanding of the economic impact of regulation. A relatively simple way to clarify many of these issues in future reports would be to provide tables that would show a step-by-step derivation of each benefit-cost estimate. In developing such a table for my own use, I found that the OMB made an arithmetical error on the benefit-cost ratio for social regulation - in this case, leading to a $\$ 30$ billion understatement of benefits.

The OMB report has been criticized for ignoring several key economic aspects of regulation (Hopkins, 1997; Dudley and Antonelli, 1997). First, the report does not estimate how regulation affects transfers of wealth among different groups, such as producers and consumers. Of course, transfers should not be listed as a "cost" of regulation. But in many cases, the size of the transfer is potentially quite large relative to the static cost of regulation; indeed, the transfer may be the purpose behind the regulation. Estimating the size of transfers can help the public and policymakers to identify the likely winners and losers from different regulations. It can also point out regulations that may be desirable on distributional grounds even if they do not pass a strict benefit-cost test. Finally, such information can be useful in deciding whether regulation is the most efficient way to pursue a desired transfer.

A second, more contentious issue relates to including certain paperwork costs-most notably those from completing tax forms. Because the average person views filling out tax forms as a type of government regulation, that burden should be included in the report in some form. However, there is an argument for keeping this category separate. Estimating the benefits and costs of the tax code, including both paperwork and efficiency costs, in a way that makes all transfers clear, is a Herculean task. Changes in the amount of paperwork associated with filling out tax forms may often alter the benefits, efficiency, and transfers in the tax code as well. Rather than attempting to resolve these issues, it may be best simply to report the raw estimate of paperwork costs in a separate category.

A third issue concerns the extent to which agencies collect information on the full array of regulatory tools they use. Recent research suggests that agencies overseen by the OMB have a great deal of information on major rule-makings, but very little information on minor rule-makings (Hahn, 1998). Knowledge on agencies not 
overseen by the OMB is generally even less complete. Moreover, knowledge of the economic impacts of alternative forms of regulation, such as licensing, permitting, guidelines, enforcement, administrative orders, and letters of opinion is minimal (U.S. House of Representatives, 1997). Both the agencies and academics can contribute to greater understanding here-first by documenting the impacts of minor rulemakings and then examining the relationship between different kinds of rulemaking. For example, as agencies are constrained in their efforts to pass major rules, they can be expected to use other regulatory instruments. The extent and impact of such behavior has not been documented.

Finally, the OMB should play a critical analytical role in regulatory analysis and should not simply pass along the estimates developed by other agencies. The OMB report takes the analysis contained in each agency's regulatory assessment as gospel, offering no additional analysis or insight based on its own detailed knowledge of individual regulations. The agency should focus its efforts on developing good incremental estimates of the impacts of individual regulations, an area in which it has a clear comparative advantage.

The OMB argues that there is insufficient evidence to recommend eliminating any specific regulatory programs. Surely, the demands of politics must play a role in this refusal to judge, or even to question. At a minimum, the OMB should ask those agencies who claim large net benefits for a program without a strong analytical basis to substantiate their view; if this means that the agencies need to fund research to evaluate their programs, so be it. Even if the OMB is not comfortable advocating the elimination or reform of programs, it might at least organize the evidence in such a way as to facilitate comparisons. For example, the OMB could develop a scorecard for individual regulations, regulatory programs, and statutes to facilitate determining which regulations, programs, and laws are likely to pass a benefit-cost test. When the maximum net benefits associated with a proposed rule are small or negative, then the agency should have to offer some additional justification for its regulation.

A slightly more aggressive $\mathrm{OMB}$ could easily specify laws and regulations for elimination or substantial reform. Table 1 provides suggestions for a number of laws and regulations that should be targets for elimination. The programs include both economic and social regulation. As can be seen from the table, annual welfare losses are in the billions of dollars for some programs. There is also ample room for significantly reforming regulatory programs. For example, expenditures on the Superfund program to clean hazardous waste sites could be dramatically reduced while enhancing economic efficiency and reducing overall risk (Viscusi and Hamilton, forthcoming).

Even if my suggestions for improving policy analysis are implemented, a very real question exists as to how such analysis would affect policy outputs. There are certainly cases in which analysis is ignored or manipulated to achieve political ends. However, there is a stronger argument that carrying out economic analysis, and exposing such analysis to sunshine and reassessment, should encourage politicians to pursue more efficient policies (Morgenstern, 1997).

It may be that the Office of Management and Budget, as an arm of the executive branch, will find it institutionally difficult to pursue an aggressive advocacy of 
Table 1

\section{Regulations and Programs That Could Be Targeted For Elimination}

\begin{tabular}{|c|c|c|}
\hline Regulation/Act & Description & Welfare Loss \\
\hline $\begin{array}{l}\text { International Trade } \\
\text { Restrictions }\end{array}$ & $\begin{array}{l}\text { Various tariffs and quotas constrain } \\
\text { international trade. }\end{array}$ & $\begin{array}{l}\text { \$3.5 billion annual welfare } \\
\text { loss. }(1990 \$)\end{array}$ \\
\hline Jones Act & $\begin{array}{l}\text { Ships travelling between U.S. ports } \\
\text { must be built in U.S. shipyards, } \\
\text { owned by U.S. citizens, and } \\
\text { operated by an American crew. }\end{array}$ & $\begin{array}{l}\$ 2.8 \text { billion annual welfare } \\
\text { loss }(1991 \$)\end{array}$ \\
\hline Milk Marketing Orders & $\begin{array}{l}\text { USDA price discrimination scheme } \\
\text { raises the price of fluid milk and } \\
\text { drives down the price of } \\
\text { manufactured milk products. }\end{array}$ & $\begin{array}{l}\$ 343-\$ 608 \text { million annual } \\
\text { welfare loss }(1985 \$)\end{array}$ \\
\hline Davis-Bacon Act & $\begin{array}{l}\text { Federally funded construction projects } \\
\text { are required to pay laborers } \\
\text { "prevailing wages." }\end{array}$ & $\begin{array}{l}\$ 200 \text { million annual } \\
\text { welfare loss }(1988 \$)\end{array}$ \\
\hline $\begin{array}{l}\text { Corporate Average Fuel } \\
\text { Economy Standards }\end{array}$ & $\begin{array}{l}\text { Each auto manufacturer must meet } \\
\text { federal average fuel economy } \\
\text { standards. }\end{array}$ & $\begin{array}{l}\text { \$4 billion welfare loss from } \\
1978 \text { through } 1989 \\
(1990 \$)\end{array}$ \\
\hline Land Disposal Regulation & $\begin{array}{l}1995 \text { Rule prohibits the disposal of } \\
\text { various untreated hazardous wastes. }\end{array}$ & $\begin{array}{l}\$ 143 \text { million annual } \\
\text { expected cost. Benefits } \\
\text { are not monetized } \\
(1992 \$)\end{array}$ \\
\hline Off-Label Drug Use & $\begin{array}{l}\text { Manufacturers cannot legally advertise } \\
\text { a pharmaceutical product for any } \\
\text { use that the FDA has not specifically } \\
\text { approved. }\end{array}$ & Not available \\
\hline Glass-Steagall Act & $\begin{array}{l}1933 \text { Act prohibits commercial banks } \\
\text { from underwriting corporate } \\
\text { securities. }\end{array}$ & Not available \\
\hline
\end{tabular}

Sources: Beales (1996), Dardis and Bedore (1990), Hahn and Hird (1991), Hufbauer and Elliott (1994), Kroszner and Rajan (1994), Leone and Parkinson as cited by Crandall (1992), U.S. EPA (1995), and U.S. ITC (1995).

regulatory reform, since this stance will inevitably involve conflict with other agencies in the executive branch. One way to strengthen the OMB's hand would be to have the Council of Economic Advisers play a co-equal role in the development of the report. Currently, the CEA helps on the report, but the OMB is primarily responsible for the drafting. Elevating the CEA's role could help reduce the scope for political meddling.

Another alternative is to provide some competition to the OMB in the form of a Congressional Office of Regulatory Analysis. Just as both the Congressional Budget Office and the OMB develop budget estimates, and each is disciplined by the existence of the other, it may be useful to have a parallel Congressional office on the regulatory side. Such an office could provide an alternate source of information and stimulate improved analysis and review of agency rules within the executive branch. High-quality annual or biannual reports on regulation by these agencies could help elevate the level of public discussion. 


\section{Conclusion}

Politicians frequently hear from voters and business about the evils of regulation, but they also see social regulation as an increasingly attractive mechanism for redistributing wealth, given fiscal constraints. Thus, it is not surprising that the reaction to the OMB report was mixed. Those politicians wishing to curb the excesses of social regulation were generally disappointed with the OMB report for not going far enough. Those politicians who see benefit-cost analysis as a threat to social programs, rather than a way of improving them, took solace in the fact that the OMB report found that total regulatory benefits exceed cost.

The primary contribution of the OMB (1997) report is to lend legitimacy to the idea that policymakers should, where possible, quantify and compare benefits and costs before making major regulatory decisions. However, the report falls short as a critical document; it fails to ask difficult questions-or any questions at all-of the agencies carrying out regulations, and fails to confront a body of research that suggests that a substantial share of government regulations would not pass a benefit-cost test.

The OMB's (1997) report also has the value of highlighting the limitations of our knowledge in many areas. For example, we still know very little about the benefits and costs of antitrust, banking and security regulation, and regulation aimed at protecting consumers from fraud. We know very little about the dynamic impacts of regulation on innovation, investment, and productivity. We know little about designing political institutions that promote more efficient regulation. Finally, academics can be helpful in providing new insights on whether benefit and cost estimates for proposed regulations tend to be overstated or understated, remembering that proponents may be overly optimistic and that affected industries may cry wolf. These gaps in our understanding offer great opportunities for researchers who wish to produce knowledge useful for policymakers.

- The helpful comments of Robert Crandall, Harold Furchtgott-Roth, Jay Hamilton, Randy Kroszner, Robert Litan, Andrew Mahony, John Morrall, Richard Schmalensee, Robert Stavins, Daniel Sumner, Leigh Tripoli, Larry White, Clifford Winston, and Fumie Yokota are gratefully acknowledged. The views in this paper reflect those of the author and do not necessarily represent the views of the institutions with which he is affiliated.

\section{References}

Arrow, Kenneth J., et al., Benefit-Cost Analysis in Environmental, Health, and Safety Regulation: A Statement of Principles. Washington, DC: AEI Press, 1996.

Beales, J. Howard, "New Uses for Old Drugs." In R. Helms, ed., Competitive Strategies in the Pharmaceutical Industry. Washington, DC: AEI Press, 1996.
Crandall, Robert W., Christopher DeMuth, Robert W. Hahn, Robert E. Litan, Pietro S. Nivola, and Paul R. Portney, An Agenda for Reforming Federal Regulation. Washington, DC: AEI and Brookings, 1997.

Dardis, Rachel, and Bonnie Bedore, "Consumer and Welfare Losses from Milk Marketing 
Orders," Journal of Consumer Affairs, 1990, 24:2, 366-80.

Dudley, Susan E., and Angela Antonelli, "Congress and the Clinton OMB," Regulation, 1997, 20:4, 17-23.

General Accounting Office, Regulatory Burden: Recent Studies, Industry Issues, and Agency Initiatives. GAO/GGD-94-28, December 1993.

Guasch, J. Luis, and Robert W. Hahn, "The Costs and Benefits of Regulation: Implications for Developing Countries," World Bank Research Observer, forthcoming.

Hahn, Robert W., "Regulatory Reform: What Do the Government's Numbers Tell Us?" In R. Hahn, ed., Risks, Costs, and Lives Saved: Getting Better Results from Regulation. New York: Oxford University Press and AEI Press, 1996.

Hahn, Robert W., Reviving Regulatory Reform: A Global Perspective. New York: Cambridge University Press and AEI Press, 1998, forthcoming.

Hahn, Robert W., and John A. Hird, "The Costs and Benefits of Regulation: Review and Synthesis," Yale Journal on Regulation, 1991, 8:1, 233-78.

Hazilla, Michael, and Raymond J. Kopp, “The Social Cost of Environmental Quality Regulations: A General Equilibrium Analysis," Journal of Political Economy, 1990, 98:4, 853-73.

Hopkins, Thomas D., "Clost of Regulation: Filling the Gaps," Report Prepared for the Regulatory Information Service Center. Washington, DC, August 1992.

Hopkins, Thomas D., OMB's Regulatory Accounting Report Falls Short of the Mark. St. Louis, Missouri: Center for the Study of American Business, Washington University, November 1997.

Hufbauer, Gary C., and Kimberly A. Elliott, Measuring the Costs of Protection in the United States. Washington DC: Institute for International Economics, 1994.

Jaffe, Adam B., et al., “Environmental Regulation and the Competitiveness of U.S. Manufacturing: What Does the Evidence Tell Us?" Journal of Economic Literature, March 1995, 33:1, 132-63.

Kroszner, Randall S., and Raghuram G. Rajan, "Is the Glass-Steagall Act Justified? A Study of the U.S. Experience with Universal Banking Before 1933," The American Economic Review, 1994, 84:4, 810-32.

Leone, Robert A., and Thomas Parkinson, as cited by Crandall, Robert W., "Policy Watch: Corporate Average Fuel Economy Standards," Journal of Economic Perspectives, 1992, 6:2, 17180.

Morrall, John F., "A Review of the Record," Regulation, November/December 1986, 10, 2534.
Morgenstern, Richard D., ed., Economic Analyses at EPA: Assessing Regulatory Impact. Washington, DC: Resources for the Future, 1997.

Organization for Economic Co-Operation and Development, Regulatory Impact Analysis: Best Practices in OECD Countries. Paris: Organization for Economic Co-Operation and Development, 1997.

Office of Management and Budget, Economic Analysis of Federal Regulations Under Executive Order No. 12866. Washington, DC: Office of Management and Budget, January 11, 1996a.

Office of Management and Budget, More Benefits Fewer Burdens: Creating A Regulatory System that Works for the American People. A Report to the President on the Third Anniversary of Executive Order 12866. Washington, DC: Office of Management and Budget, December 1996b.

Office of Management and Budget, Report to Congress on the Costs and Benefits of Federal Regulations. Washington, DC: Office of Management and Budget, September 30, 1997.

Tengs, Tammy O., and John D. Graham, "The Opportunity Costs of Haphazard Social Investments in Life-Saving." In R. Hahn, ed., Risks, Costs and Lives Saved: Getting Better Results from Regulation. New York: Oxford University Press and AEI Press, 1997.

U.S. Environmental Protection Agency, Environmental Investments: The Cost of a Clean Environment. Washington, DC: U.S. Environmental Protection Agency, Office of Policy, Planning and Evaluation, October 1990.

U.S. Environmental Protection Agency, Regulatory Impact Analysis of the Supplemental Proposed Rule Applying Phase IV Land Disposal Restrictions to Newly Identified Mineral Processing Wastes. Washington, DC: U.S. Environmental Protection Agency, Office of Solid Waste, December 1995.

U.S. House of Representatives, Committee on Commerce, Survey of Federal Agencies on Costs of Federal Regulations. Staff Report. Washington, DC: U.S. Government Printing Office, January 1997.

U.S. International Trade Commission, The Economic Effects of Significant U.S. Import Restraints: First Biannual Update. Washington, DC: U.S. International Trade Commission, Office of Economics and Industries, December 1995.

Viscusi, W. Kip, "Economic Foundations of the Current Regulatory Reform Efforts," Jourmal of Economic Perspectives, 1996, 10.3, 119-34.

Viscusi, W. Kip, and James T. Hamilton, “Are Risk Regulators Rational? Evidence from Hazardous Waste Cleanup Decisions," American Economic Review, forthcoming.

Winston, Clifford, "U.S. Industry Adjustment to Economic Deregulation," Joumal of Economic Perspectives, Summer 1998, 12: 3, 89-110. 
http://www.jstor.org

\section{LINKED CITATIONS}

- Page 1 of 2 -

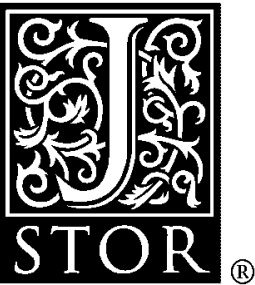

You have printed the following article:

Policy Watch: Government Analysis of the Benefits and Costs of Regulation

Robert W. Hahn

The Journal of Economic Perspectives, Vol. 12, No. 4. (Autumn, 1998), pp. 201-210.

Stable URL:

http://links.jstor.org/sici?sici=0895-3309\%28199823\%2912\%3A4\%3C201\%3APWGAOT\%3E2.0.CO\%3B2-5

This article references the following linked citations. If you are trying to access articles from an off-campus location, you may be required to first logon via your library web site to access JSTOR. Please visit your library's website or contact a librarian to learn about options for remote access to JSTOR.

\section{References}

Social Cost of Environmental Quality Regulations: A General Equilibrium Analysis

Michael Hazilla; Raymond J. Kopp

The Journal of Political Economy, Vol. 98, No. 4. (Aug., 1990), pp. 853-873.

Stable URL:

http://links.jstor.org/sici?sici=0022-3808\%28199008\%2998\%3A4\%3C853\%3ASCOEQR\%3E2.0.CO\%3B2-3

Environmental Regulation and the Competitiveness of U.S. Manufacturing: What Does the Evidence Tell Us?

Adam B. Jaffe; Steven R. Peterson; Paul R. Portney; Robert N. Stavins

Journal of Economic Literature, Vol. 33, No. 1. (Mar., 1995), pp. 132-163.

Stable URL:

http://links.jstor.org/sici?sici=0022-0515\%28199503\%2933\%3A1\%3C132\%3AERATCO\%3E2.0.CO\%3B2-G

Is the Glass-Steagall Act Justified? A Study of the U.S. Experience with Universal Banking Before 1933

Randall S. Kroszner; Raghuram G. Rajan

The American Economic Review, Vol. 84, No. 4. (Sep., 1994), pp. 810-832.

Stable URL:

http://links.jstor.org/sici?sici=0002-8282\%28199409\%2984\%3A4\%3C810\%3AITGAJA\%3E2.0.CO\%3B2-M 
http://www.jstor.org

\section{LINKED CITATIONS \\ - Page 2 of 2 -}

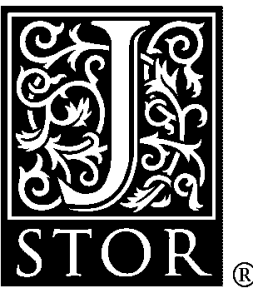

\section{Economic Foundations of the Current Regulatory Reform Efforts}

W. Kip Viscusi

The Journal of Economic Perspectives, Vol. 10, No. 3. (Summer, 1996), pp. 119-134.

Stable URL:

http://links.jstor.org/sici?sici=0895-3309\%28199622\%2910\%3A3\%3C119\%3AEFOTCR\%3E2.0.CO\%3B2-M

\section{U.S. Industry Adjustment to Economic Deregulation}

Clifford Winston

The Journal of Economic Perspectives, Vol. 12, No. 3. (Summer, 1998), pp. 89-110.

Stable URL:

http://links.jstor.org/sici?sici=0895-3309\%28199822\%2912\%3A3\%3C89\%3AUIATED\%3E2.0.CO\%3B2-H 